\title{
Effects of heavy metals toxicity on the biochemical response in tomato plants grown in contaminated silt-soil
}

\author{
A. Saeed ${ }^{1}$, M. Sohail ${ }^{2}$, N. Rashi ${ }^{3}$ and M. Iqbal ${ }^{4 *}$ \\ ${ }^{1}$ Food and Biotechnology Research Centre, PCSIR Laboratories Complex, Lahore-54600, Pakistan \\ ${ }^{2}$ Institute of Chemistry, Punjab University, Lahore-54570, Pakistan \\ ${ }^{3}$ School of Biological Sciences, Punjab University, Lahore-54570, Pakistan \\ ${ }^{4}$ Centre for Applied Molecular Biology, 87-West Canal Bank Road, Thoker Niaz Baig, Lahore Pakistan
}

\begin{abstract}
Toxic effects of $\mathrm{Cu}^{2+}, \mathrm{Zn}^{2+}$ and $\mathrm{Cd}^{2+}$ in tomato plants were the reduction in vegetative growth of seedlings and also in flowering and fruiting. Toxicity of these heavy metals resulted in a reduction in chlorophyll a, chlorophyll b and soluble sugars, but in an increase in proline. Toxic metal stress caused a $71.71,77.70$ and $11.90 \%$ increase in the activities of peroxidase, catalase and ascorbic acid oxidase, respectively. With respect to the total uptake of $\mathrm{Cd}^{2+}$, the biggest sink for the metal was provided by roots with $72.80 \%$ retention followed by $22 \%$ in the stem. Accumulation of $\mathrm{Cd}^{2+}$ and $\mathrm{Zn}^{2+}$ gradually increased in the order of root, stem and leaves, but for $\mathrm{Cu}^{2+}$ that was reversed, that is, it increased in the order of leaf, stem and root. A new consideration of metals bioavailability is discussed in terms of their respective solubility product constants, $\mathrm{pH}$ of precipitation, and metal complexation.
\end{abstract}

Keywords: Metal ions; Bioavailability ; Growth responses; Toxicology ; Contaminated silt-soil

\section{Introduction}

Several toxic metals have not only become ubiquitous, but have heavily loaded the environment, posing serious threats to humans and other forms of life (Wilson and Pyatt, 2007; Saeed et al. 2009). The lasting negative impact of these metals in the environment is due to their non-biodegradable nature, long biological half-lives ranging from $10-3,000$ years, and the potential to accumulate in different body parts (Han, 2007). Excessive exposure to such metals may cause a variety of diseases, some of which may also have mutagenic and carcinogenic consequences (Gorsuch, 1991; Bo et al. 2009). Vegetables are also reported to have the potential to accumulate heavy metals when grown on contaminated soils, or when irrigated with sewage and wastewaters (Gorsuch, 1991; Bo et al. 2009). At higher levels, heavy metals cause growth inhibition and physio-biochemical disorders (Claire et al. 1991). Excess concentrations of some of these $(\mathrm{Cd}, \mathrm{Cr}, \mathrm{Cu}, \mathrm{Ni}, \mathrm{Zn})$ in the soil have caused disruptionof ecosystems (Meagher, 2000). Cadmium is among the most serious metal toxicants (WHO, 1992). The metal is particularly dangerous as plants growing even in the low-level contaminated soils can absorb and accumulate $\mathrm{Cd}$ in their edible tissues in large quantities, without any visible indication, thereby becoming a part of the human food chain (Monteiro et al. 2008). A recent study in Europe noted the contents of $\mathrm{Cd}$ in vegetables to be higher than the known safe thresholds (Peris et al. 2007). Since cereals, potatoes and vegetables account for $70 \%$ of the dietary intake (Grawe, 1996), and Cd is reported to have high mobility from soil to plants (Jansson, 2002; Liu et al. 2007), the metal has been the subject of increasing interest of study (Yujing et al. 2008). Understanding the factors related with the uptake of heavy metals by plants, the resultant stress response, and thus the damage caused to the physiological functioning of plants, have been suggested to be critical to the long-term safety and conservation of agricultural resources and ecosystems (Monteiro et al. 2009). Consideration of the level of uptake, translocation, and accumulation of toxic metals in different plant parts is of significance, as it has been suggested that plants might react as the first line of defense against toxicity by reducing metal concentration in active organs or cells through selective exclusion during uptake, excretion, or retention in the roots (Wu et al. 2005). Metal toxicity causes interference with physiological functioning of plants, such as deleterious effects on the biosynthesis of chlorophylls (Qin, 1994; Hattab et al. 2009), inhibition of growth in plants grown in metals-contaminated soil (Hattab et al. 2009), and enhanced proteins content due to greater synthesis of metalbinding proteins, plant-metal chelators and antioxidant

\footnotetext{
*Corresponding author. e-mail: iqbalmdr@brain.net.pk
} 
enzymes (Gratao et al. 2008; Nayek et al. 2010). Metal stress response causes altered levels of plant protective enzymes, including peroxidase, catalase and ascorbate peroxidase (Cheng, 2003; Israr et al. 2011), and accumulation of free proline (Cheng, 2003).

Tomato plant was selected as plant material as reports on the effect of heavy metals on physiological and biochemical parameters in tomato are rare. The aim of the present work is to study the accumulation of $\mathrm{Cu}^{2+}, \mathrm{Zn}^{2+}$ and $\mathrm{Cd}^{2+}$ by various parts of the tomato plant at different stages of growth when grown in the silt-soil spiked with $\mathrm{Cu}^{2+}, \mathrm{Zn}^{2+}$ and $\mathrm{Cd}^{2+}$ in a multimetal combination. Some physiological and biochemical parameters like their effects on proline and enzymes are also studied.

\section{Materials and methods}

\section{Silt-soil preparation}

Silt-soil used in the study was collected from a canal that bisects the city of Lahore which on its way receives flushing of domestic wastewater and run-off water from several points of inlet. The collected silt-soil was air-dried, homogenized, and passed through $1 \mathrm{~mm}$ sieve to remove stones and debris. To the silt-soil, a mixture of salts comprising 1000 $\mathrm{mg} \mathrm{Cd}\left(\mathrm{NO}_{3}\right)_{2} \cdot 4 \mathrm{H}_{2} \mathrm{O}, 1000 \mathrm{mg} \mathrm{Cu}\left(\mathrm{NO}_{3}\right)_{2} \cdot 3 \mathrm{H}_{2} \mathrm{O}$ and 1000 $\mathrm{mg} \mathrm{ZnCl}_{3}$ per kg silt-soil, which corresponded to $364.40 \mathrm{mg}$ $\mathrm{Cd}^{2+}, 263.0 \mathrm{mg} \mathrm{Cu}^{2+}$ and $479.85 \mathrm{mg} \mathrm{Zn}^{2+} / \mathrm{Kg}$ of the silt-soil was then added, well-mixed and transferred to PVC pots (33 $\left.\mathrm{cm}^{2}\right)$. The pots were shifted inside a nylon-mesh net $(18 \mathrm{~m} \mathrm{x}$ $9 \mathrm{~m} \mathrm{x} 4.8 \mathrm{~m}$ ) which was routinely monitored for temperature, humidity and light. Tomato (Lycopersicum esculentum) seeds procured from the Seed Corporation of Pakistan, Lahore were sown for nursery seedlings directly to the PVC pots filled with the metals-contaminated silt-soil. Silt-soil without the added mixture of heavy metal salts was run as the control for raising seedling nursery and plant growth studies.

\section{Physicochemical analysis of the silt-soil and tomato plants}

Electrical conductivity and $\mathrm{pH}$ of the silt-soil were determined using the standard methods of soil analysis (Rhoades, 1982). Organic matter was calculated as the amount of carbon present in the silt-soil following the procedure of Walkey and Black (1934). Total heavy metal contents $\left(\mathrm{Cu}^{2+}\right.$, $\left.\mathrm{Zn}^{2+}, \mathrm{Cd}^{2+}\right)$ were determined in accordance with Rump (2008) using atomic absorption spectrophotometer (SOLAAR, Unicam 969, UK), and total cationic contents $\left(\mathrm{Na}^{+}, \mathrm{K}^{+}\right)$were analyzed by flame photometer (Jenway
PFP7, UK). Bioavailable fractions of $\mathrm{Cu}^{2+}, \mathrm{Zn}^{2+}$ and $\mathrm{Cd}^{2+}$ in the silt-soil were determined according to Novozamsky and coworkers (1993) by atomic absorption spectrophotometer. Cation exchange capacity of the silt-soil was determined as the concentration of exchangeable cations $\left(\mathrm{Na}^{+}, \mathrm{K}^{+}\right)$by flame photometer (Radojevic and Bashkin, 2007). Plants were analyzed for $\mathrm{Cu}^{2+}, \mathrm{Zn}^{2+}$ and $\mathrm{Cd}^{2+}$ following the standard AOAC procedure (2005) which was done to determine their tendency of accumulation in root, stem, leaf, fruit of the tomato plant at seedling, vegetative, flowering-fruiting stage of growth, and their concentrations were calculated on fresh weight basis.

\section{Determination of chlorophyll, sugars, protein and protine}

Chlorophylls a and b were extracted from fresh leaf disks following the method of Lichtenthaler (1987). Soluble sugars were extracted from fresh plant material by the method of Yemm and Willis (1954). Total proteins were determined according to the standard AOAC-Kjeldahl procedure (2005). Proline content was determined according to Bates et al. (1973), and proline concentration was calculated by plotting a calibration curve using toluene as the blank.

\section{Determination of antioxidant enzymes activities}

Catalase activity was determined as the rate of decomposition of $\mathrm{H}_{2} \mathrm{O}_{2}(240 \mathrm{~nm} / \mathrm{min})$ against $0.036 \% \mathrm{H}_{2} \mathrm{O}_{2}$ used as the blank and expressed as $\mu \mathrm{mol}$ of $\mathrm{H}_{2} \mathrm{O}_{2}$ decomposed $\mathrm{min} / \mathrm{g}$ fresh weight (Aebi, 1984). The activity was calculated using molar extinction co-efficient of $\mathrm{H}_{2} \mathrm{O}_{2}$ at $240 \mathrm{~nm} \mathrm{(36}$ $\mathrm{L} / \mathrm{mol} / \mathrm{cm}$ ). One unit of catalase activity catalyzes the conversion of $1 \mu$ mole of $\mathrm{H}_{2} \mathrm{O}_{2}$ to $\mathrm{H}_{2} \mathrm{O}$ and $\mathrm{O}_{2} / \mathrm{min}$. Peroxidase activity was measured as the increase in absorbance at 420 $\mathrm{nm} / \mathrm{min}$ due to oxidation of pyrogallol (Chance, 1955). Reaction mixture without the addition of crude enzyme extract was used as the blank. Peroxidase activity was calculated using molar extinction co-efficient of pyrogallol at 420 $\mathrm{nm}(19 \mathrm{~L} / \mathrm{mol} / \mathrm{cm})$ and expressed as $\mu \mathrm{mol}$ of $\mathrm{H}_{2} \mathrm{O}_{2}$ decomposed $/ \mathrm{min} / \mathrm{g}$ fresh weight of leaves. A peroxidase unit is defined as the amount of enzyme that catalyzes the oxidation of $1 \mu$ mole of pyrogallol to purpurogallin/min. Ascorbate peroxidase assay was done by recording the decrease in absorbance at $290 \mathrm{~nm}$ due to the oxidation of ascorbate to dehydroascorbate by $\mathrm{H}_{2} \mathrm{O}_{2}$ (Nakano and Asada, 1981). Ascorbate peroxidase activity was calculated using molar extinction co-efficient of sodium ascorbate at $290 \mathrm{~nm}(2800$ $\mathrm{L} / \mathrm{mol} / \mathrm{cm}$ ) and expressed in $\mu \mathrm{mol}$ of ascorbate oxidized $/ \mathrm{min} / \mathrm{g}$ fresh weight of leaves. One unit of the enzyme activity is defined as the oxidation of $1 \mu$ mole of 
ascorbate to dehydroascorbate/min.

Reproducibility and data analysis

Data presented in the study are the mean values of three separate experiments. Statistical analysis of the data was done using the Duncan's new multiple range test at $p \leq 0.05$ (Steel and Torrie, 1996).

\section{Results and discussion}

Physicochemical characteristics of the contaminated siltsoil

Physicochemical characteristics of the silt-soil spiked with $\mathrm{Cu}^{2+}, \mathrm{Zn}^{2+}$ and $\mathrm{Cd}^{2+}$, compared with the control (Table I). The silt-soil in the native state (without metals contamination) had $5.3 \%$ clay, $0.38 \%$ organic matter (OM), and the remainder being silt. These observations indicate that both the clay and OM fractions were low. $\mathrm{pH}$ of the native silt-soil was slightly alkaline, which fell from 7.9 to 7.7 on its spiking with $\mathrm{Cu}^{2+}, \mathrm{Zn}^{2+}$ and $\mathrm{Cd}^{2+}$ (Table I). Similar small $\mathrm{pH}$ reduction was reported on soil contamination with heavy metals (Nayek et al. 2010). Cation exchange capacity (CEC) of both the metals-contaminated and control silt-soil was low, respectively, 14.5 and $15.5 \mathrm{meq} / 100$ (Table I). The CEC of soil is a measure of its ability to bind cations, and is an indicator of the negatively charged binding sites on the soil surface where cations are adsorbed (Radojevic and Bashkin, 2007).

Table I. Physicochemical characteristics of the silt-soil contaminated with heavy metals $\left(\mathrm{Cd}^{2+}, \mathrm{Cu}^{2+}, \mathrm{Zn}^{2+}\right)$

\begin{tabular}{lcccc}
\hline Soil used & \multicolumn{3}{c}{ Physicochemical characteristics } \\
\cline { 2 - 5 } & $\mathrm{pH}$ & $\mathrm{EC}$ & OM & CEC \\
& $\left(25^{\circ} \mathrm{C}\right)$ & $(\mu \mathrm{S} / \mathrm{cm})$ & $(\%)$ & $(\mathrm{meq} / 100 \mathrm{~g})$ \\
\hline Contaminated silt-soil & $7.7 \pm 0.02^{\mathrm{a}}$ & $873.5 \pm 5.12^{\mathrm{a}}$ & $0.41 \pm 0.04^{\mathrm{a}}$ & $14.83 \pm 0.66^{\mathrm{a}}$ \\
Silt-soil as collected (control) & $7.9 \pm 0.03^{\mathrm{b}}$ & $646.0 \pm 4.17^{\mathrm{b}}$ & $0.38 \pm 0.02^{\mathrm{a}}$ & $15.50 \pm 0.10^{\mathrm{a}}$ \\
\hline
\end{tabular}

$\mathrm{EC}=$ electrical conductivity; $\mathrm{OM}=$ organic matter; $\mathrm{CEC}=$ cation exchange capacity; all values are mean of concurrent triplicate observations; \pm standard deviation; values with different alphabets are significantly different from each other at $\mathrm{p}=0.05$ (Duncan's multiple range test)

\section{Bioavailability of metals}

Bioavailability of metal ions in the spiked silt-soil was in the order of $\mathrm{Cd}^{2+}>\mathrm{Cu}^{2+}>\mathrm{Zn}^{2+}$ (Table II), which was only $1.7 \%$, $0.98 \%$ and $0.82 \%$ of their respective total contents. Similar trend of metal mobility $\left(\mathrm{Cd}^{2+}>\mathrm{Cu}^{2+}>\mathrm{Zn}^{2+}\right)$ has been earlier reported (Yobouet et al. 2010). The solubility of $\mathrm{Cu}^{2+}, \mathrm{Zn}^{2+}$ and $\mathrm{Cd}^{2+}$, calculated from their respective $\mathrm{K}_{\mathrm{sp}}$ values as their hydroxides, carbonates and phosphates at the spiking con- centrations of these metals used in the present studies were low (Table III). Since most cultivation soils are slightly alkaline, low solubility of metals may be regarded as a natural counter-mechanism to the survival of plants growing in contaminated soils. No previous study on metal stress and toxicity in plants has considered the solubility of metals as related to $\mathrm{K}_{\mathrm{sp}}$, concentration of the metals present, and the $\mathrm{pH}$ of their precipitation.

Effects of heavy metals on chlorophyll, soluble sugars, protein and prolines

Leaves of tomato plants grown in the silt-soil spiked with $\mathrm{Cu}^{2+}, \mathrm{Zn}^{2+}$ and $\mathrm{Cd}^{2+}$ showed a significant decrease in $81.8 \%$ and $50.9 \%$ in chlorophylls a and b, respectively, accompanied by symptoms of chlorosis, browning of leaf margins, and stunted growth (Tables IV and V). Similar phytotoxic symptoms have been linked with $\mathrm{Cd}^{2+}$ and $\mathrm{Cu}^{2+}$ contamination (Hattab et al. 2009). Chlorosis from excess $\mathrm{Cd}^{2+}$ has been suggested to be due to interaction with foliar iron (Das et al. 1997), or suppressed iron uptake by plants (Haghiiri, 1974). Pea seedlings exposed to high $\mathrm{Cd}^{2+}$ and $\mathrm{Cu}^{2+}$ showed drastic decrease of chlorophyll a and chlorophyll b (Hattab et al. 2009). Reduction of chlorophylls a and b in lettuce exposed to $\mathrm{Cd}^{2+}$ contamination has also observed (Monteiro et al. 2009). Copper was reported to modify the physiological processes related with chlorophyll degradation due to the peroxidation of chloroplast membranes (Baszynski et al. 
Table II. Total metal contents $\left(\mathrm{Cd}^{2+}, \mathrm{Cu}^{2+}, \mathrm{Zn}^{2+}\right)$ and their bioavailable fractions in the artificially contaminated silt-soil

\begin{tabular}{|c|c|c|c|c|c|c|}
\hline \multirow[t]{2}{*}{ Soil used } & \multicolumn{3}{|c|}{$\begin{array}{l}\text { Total metal fractions } \\
(\mathrm{mg} / \mathrm{Kg})\end{array}$} & \multicolumn{3}{|c|}{$\begin{array}{c}\text { Bioavailable metal fractions } \\
\mathrm{mg} / \mathrm{Kg}(\%)^{*}\end{array}$} \\
\hline & $\mathrm{Cd}^{2+}$ & $\mathrm{Cu}^{2+}$ & $\mathrm{Zn}^{2+}$ & $\mathrm{Cd}^{2+}$ & $\mathrm{Cu}^{2+}$ & $\mathrm{Zn}^{2+}$ \\
\hline Heavy metals contaminated silt-soil & $364.40 \pm 7.32$ & $263.0 \pm 5.87$ & $479.74 \pm 9.21$ & $\begin{array}{c}6.20 \pm 1.26 \\
\quad(1.70)\end{array}$ & $\begin{array}{l}2.59 \pm 0.05 \\
\quad(0.98)\end{array}$ & $\begin{array}{l}3.92 \pm 0.07 \\
\quad(0.82)\end{array}$ \\
\hline Silt-soil as collected (control) & - & $22.03 \pm 0.04$ & $64.45 \pm 0.09$ & - & $\begin{array}{l}1.23 \pm 0.02 \\
(5.58)\end{array}$ & $\begin{array}{l}1.28 \pm 0.01 \\
\quad(1.99)\end{array}$ \\
\hline
\end{tabular}

*within parenthesis are given percentage bioavailable fractions of the total metal contents; all values are mean of concurrent triplicate observations; \pm standard deviation

Table III. Solubilities of $\mathrm{Cd}^{2+}, \mathrm{Cu}^{2+}$, and $\mathrm{Zn}^{2+}$ in the artificially contaminated silt-soil, calculated from their respective solubility product constants $\left(K_{\mathrm{sp}}\right)$, at the concentration* of metals added as contaminants, as the corresponding metal complexes hypothetically formed in the soil (Kolthoff et al. 1971)

\begin{tabular}{llcc}
\hline Metal complex in soil & $\mathrm{K}_{\mathrm{sp}}$ at $25^{\circ} \mathrm{C}$ & $\mathrm{pH}$ of precipitation & $\begin{array}{c}\text { Calculated solubilities at concentra } \\
\text { tions used in experimental soil }\end{array}$ \\
\hline $\mathrm{Cu}(\mathrm{OH})_{2}$ & $2.2 \times 10^{-20}$ & 5.36 & $2.29 \times 10^{-9}$ \\
$\mathrm{CuCO}_{3} \mathrm{Cu}_{3}\left(\mathrm{PO}_{4}\right)_{2}$ & $1.4 \times 10^{-10}$ & - & $3.41 \times 10^{-8}$ \\
$\mathrm{Zn}(\mathrm{OH})_{2}$ & $1.39 \times 10^{-37}$ & - & $3.24 \times 10^{-12}$ \\
$\mathrm{ZnCO}$ & $1.2 \times 10^{-17}$ & 6.61 & $4.04 \times 10^{-8}$ \\
$\mathrm{Zn}\left(\mathrm{PO}_{4}\right)_{2}$ & $1.19 \times 10^{-10}$ & - & $1.91 \times 10^{-9}$ \\
$\left.\mathrm{Cd}_{(\mathrm{OH}}\right)_{2}$ & $9.0 \times 10^{-33}$ & - & $1.07 \times 10^{-10}$ \\
$\mathrm{CdCO}_{3}$ & $5.27 \times 10^{-15}$ & -4.4 & $2.78 \times 10^{-6}$ \\
$\mathrm{Cd}_{3}\left(\mathrm{PO}_{4}\right)_{2}$ & $6.18 \times 10^{-12}$ & - & $1.60 \times 10^{-9}$ \\
\hline
\end{tabular}

${ }^{*} \mathrm{Cu}^{2+}, \mathrm{Zn}^{2+}$ and $\mathrm{Cd}^{2+}$, respectively, $263.0 \mathrm{mg}, 479.85 \mathrm{mg}$ and $364.40 \mathrm{mg} / \mathrm{Kg}$ silt-soil

decline of sugars content was related to the loss of photosynthetic pigments, and the high energy needs of plants due to oxidative stress and toxicity response (John et al. 2008; Nayek et al. 2010).
Proteins in tomato plant leaves grown in the silt-soil spiked with $\mathrm{Cu}^{2+}, \mathrm{Zn}^{2+}$ and $\mathrm{Cd}^{2+}$ showed an increase of $28.1 \%$ (Table IV). This observation is consistent with the reported increase of proteins in beans, pea, spinach and tomato plants

Table IV. Chlorophylls, proline, soluble sugars, and total protein in leaves of tomato plants grown under $\mathrm{Cd}^{2+}, \mathrm{Cu}^{2+}$, and $\mathrm{Zn}^{2+}$ toxicity

\begin{tabular}{|c|c|c|c|c|c|}
\hline \multirow[t]{2}{*}{ Tomato plant growth conditions } & & \multicolumn{4}{|c|}{ Biochemical indicators } \\
\hline & $\begin{array}{l}\text { Chlorophyll a } \\
(\mu \mathrm{g} / \mathrm{g})\end{array}$ & $\begin{array}{l}\text { Chlorophyll b } \\
(\mu \mathrm{g} / \mathrm{g})\end{array}$ & $\begin{array}{l}\text { Proline } \\
(\mu \mathrm{g} / \mathrm{g})\end{array}$ & $\begin{array}{l}\text { Soluble sugars } \\
\qquad(\mathrm{mg} / \mathrm{g})\end{array}$ & $\begin{array}{l}\text { Total proteins } \\
(\mathrm{mg} / \mathrm{g})\end{array}$ \\
\hline $\begin{array}{l}\text { Plants grown under } \\
\text { heavy metal stress }\end{array}$ & $90.11 \pm 0.05^{a}$ & $97.14 \pm 0.08^{a}$ & $0.312 \pm 0.022^{\mathrm{a}}$ & $3.46 \pm 0.03^{\mathrm{a}}$ & $0.41 \pm 0.01^{\mathrm{a}}$ \\
\hline $\begin{array}{l}\text { Control (plants grown in } \\
\text { silt-soil not contaminated } \\
\text { with heavy metals) }\end{array}$ & $496.54 \pm 2.01^{b}$ & $197.94 \pm 1.97 \mathrm{~b}$ & $0.206 \pm 0.002^{\mathrm{a}}$ & $8.15 \pm 1.51^{b}$ & $0.32 \pm 0.03^{b}$ \\
\hline $\begin{array}{l}(\%) \text { Increase }(+) / \\
\text { decrease }(-)\end{array}$ & (-) 81.85 & (-) 50.92 & $(+) 51.46$ & (-) 57.55 & $(+) 28.13$ \\
\hline
\end{tabular}

All values are mean of concurrent triplicate observations; \pm standard deviation; values with different alphabets are significantly different from each other at $\mathrm{p}=0.05$ (Duncan's multiple range test) 
(Nayek et al. 2010), wheat and Indian mustard (Chandra et al. 2009), and Beta vulgaris (Singh and Agarwal, 2007). The increase in protein content was suggested to be due to higher synthesis of metal binding proteins (Nayek et al. 2010) or plant-metal chelators and antioxidant enzymes in response to metal stress (Gratao et al. 2008). The content of proline, a proteinogenic amino acid essential for primary metabolism (Szabados and Savoure, 2009), in the tomato plants grown under the stress of $\mathrm{Cu}^{2+}, \mathrm{Zn}^{2+}$ and $\mathrm{Cd}^{2+}$ showed an increase of $51.5 \%$ (Table IV). Similar observation of proline increase was reported in Cicer arietinum grown under $\mathrm{Cd}^{2+}$ stress (Tantrey and Agnihotri, 2010), and increase in tomato, pea, beans and spinach irrigated with metals-contaminated wastewater (Nayek et al. 2010). Proline accumulation is as an indicator of stress (Alia and Saradhi, 1991). It is also regarded as an abiotic stress marker against heavy metals (Tantrey and Agnihotri, 2010).

Response of antioxidant enzymes in tomato plants grown under metal stress

Leaves of tomato plants grown in silt-soil contaminated with metals showed an increase in the activities of peroxidase $(\mu \mathrm{mol} / \mathrm{min} / \mathrm{g}$ fresh weight of tomato leaves) was from 139.64 to 239.73 , of catalse from 103.33 to 183.66 , and of ascorbate peroxidase from 1.01 to 1.13 (Fig. 1). Hyperactivity of antioxidant enzymes, such as peroxidase, catalase and ascorbate peroxidase in plants irrigated with wastewater contaminated with metals was also observed (Nayek et al. 2010). Peroxidase activity in the leaves of Raphanus sativus increased proteins in response to $\mathrm{Cd}^{2+}$ to overcome oxidative stress of the metal (El-Beltagi et al. 2010). Increase in catalase activity in tomato plants was observed when $\mathrm{Cd}^{2+}$ was spiked in the soil (Gratao et al. 2008). Likewise, ascorbate peroxidase activity was induced due to $\mathrm{Cd}^{2+}$ stress in Bechmeria nivea (Liu et al. 2007). Production of protective enzymes in plants has been regarded as a defensive mechanism to reduce oxidative stress (Liu et al. 2007). Oxidative stress, induced on the accumulation of $\mathrm{Cd}^{2+}$ within plant cells, is evident from increased $\mathrm{H}_{2} \mathrm{O}_{2}$ accumulation (Liu et al. 2007; Israr et al. 2011). $\mathrm{H}_{2} \mathrm{O}_{2}$ acts as a stress response signal and stimulates activities of several radical scavenging enzymes, including peroxidase, catalase and ascorbate peroxidase (Grattao et al. 2006). Ascorbate peroxidase plays a role in the elimination of active oxygen species and maintenance of the redox status of cells (Foyer et al. 1997).

\section{Effects of metal stress on the growth of tomato plants}

The height of tomato plants under the metal stress was reduced by $24.6 \%, 43.8 \%$ and $58.7 \%$, respectively, at the seedling, vegetative and flowering-fruiting stages (Table V). Cadmium caused retardation in the shoot growth was decreased in lettuce (Monteiro et al. 2009) and shoot of Pisum sativum (Hattab et al. 2009). Growth retardation has been regarded as one of the standard physical parameters for the evaluation of toxicity (Israr et al. 2011).

Accumulation of metals in different organs of tomato at different growth stages

The accumulation of $\mathrm{Cu}^{2+}$ and $\mathrm{Zn}^{2+}$ progressively increased in root, stem and leaf through the seedling, vegetative and
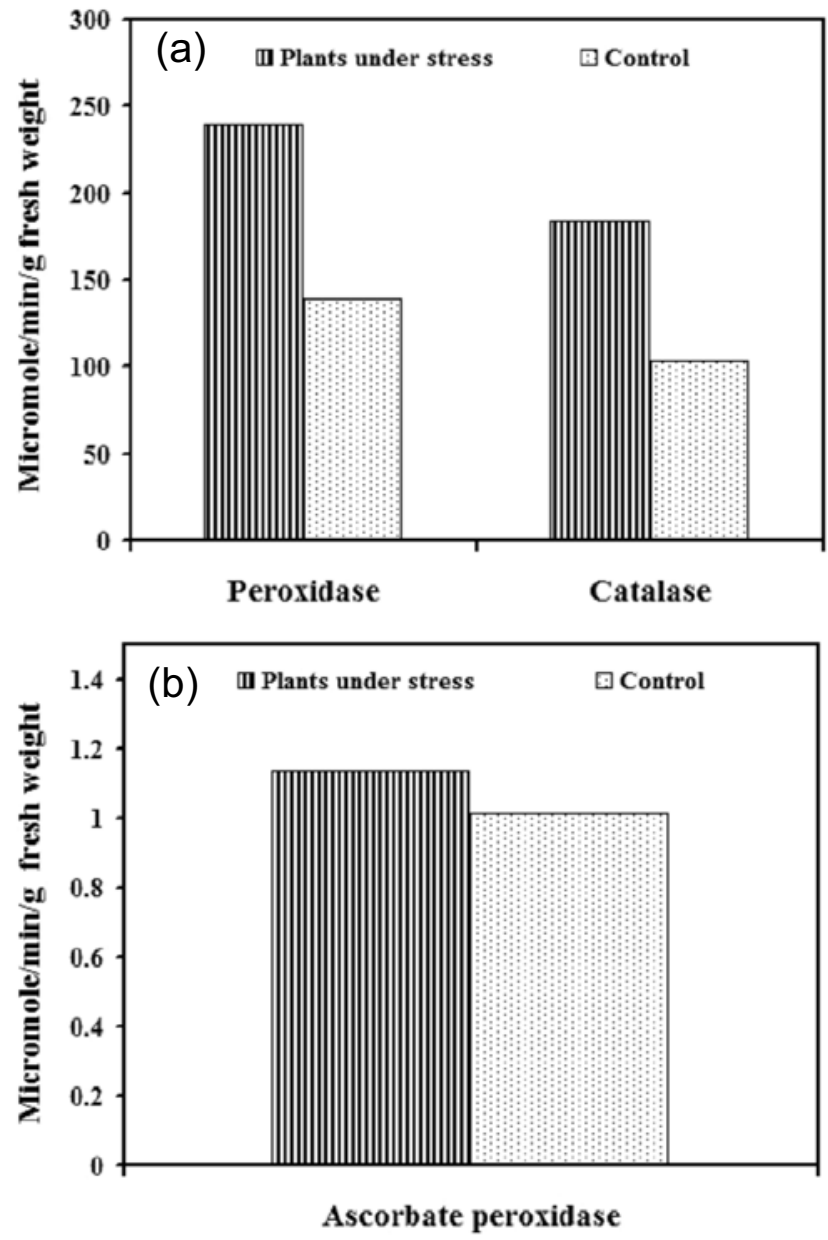

Fig. 1. Antioxidant enzyme activities of (a) peroxidase and catalase, and (b) ascorbate peroxidase in leaf of tomato plants grown under stress of heavy metals $\left(\mathrm{Cd}^{2+}, \mathrm{Cu}^{2+}, \mathrm{Zn}^{2+}\right)$. 
Table V. Growth of tomato plants grown in silt-soil contaminated with $\mathrm{Cd}^{2+}, \mathrm{Cu}^{2+}$, and $\mathrm{Zn}^{2+}$ at different developmental stages

\begin{tabular}{|c|c|c|c|}
\hline \multirow[t]{2}{*}{ Stage of plant growth } & \multicolumn{2}{|c|}{ Average height of plants $(\mathrm{cm})$} & \multirow{2}{*}{$\begin{array}{l}\text { Growth } \\
\text { reduction } \\
(\%)\end{array}$} \\
\hline & $\begin{array}{c}\text { Grown in metals } \\
\text { contaminated silt-soil }\end{array}$ & $\begin{array}{l}\text { Grown in silt-soil } \\
\text { as collected (control) }\end{array}$ & \\
\hline $\begin{array}{l}\text { Seedling stage (days } 1-10 \text {; nursery seedlings } \\
\text { upto transplantation) }\end{array}$ & $4.9 \pm 1.2$ & $6.5 \pm 1.8$ & 24.6 \\
\hline $\begin{array}{l}\text { Vegetative stage (days } 11-40 \text {; seedling } \\
\text { transplantation to flowering) }\end{array}$ & $7.7 \pm 2.2$ & $13.7 \pm 2.6$ & 43.8 \\
\hline Fruiting stage (days 41-75; flowering to fruit ripening & $31.0 \pm 4.5$ & $75.0 \pm 5.1$ & 58.7 \\
\hline
\end{tabular}

All values are mean of concurrent triplicate observations; \pm standard deviation

flowering-fruiting stages, which corresponded with the enhanced needs and greater metabolic activities as the plants grew. Accumulation of only 1.01 and $1.82 \mu \mathrm{g} / \mathrm{g} \mathrm{Cu}^{2+}$ and $\mathrm{Zn}^{2+}$ in the ripened tomato fruit, respectively, indicates less need to transfer these metals to the fruit pulp (Table VI). This observation agrees well with the report that whereas $\mathrm{Cd}^{2+}$ was transported in sufficient quantity to the aerial parts of tomato plants, it was not detected in fruits (Moral et al. 1994). Throughout the three stages of growth in the control silt-soil, the trend of accumulation was stem $>$ leaf $>$ root for $\mathrm{Zn}^{2+}$, and stem $>$ root $>$ leaf for $\mathrm{Cu}^{2+}$. In the metals-contaminated silt-soil, the trend of accumulation was root $>$ stem $>$ leaf for $\mathrm{Cd}^{2+}$ and $\mathrm{Zn}^{2+}$, with the concentration of both, 2-4 times greater in root than in stem, and several times in both these parts than in leaf. These observations indicate that root and shoot functioned as toxic metal sinks as a mechanism to combat metal toxicity. No consistent trend of tissue-partitioning was noted for $\mathrm{Cu}^{2+}$ during the three stages of growth. Partitioning of metals in different plant parts is a common strategy to avoid toxicity (Monteiro et al. 2009). The biggest sink for $\mathrm{Zn}^{2+}$ with $52.6 \%$ was also in the root, followed by $24.4 \%$ and $23.1 \%$ in the stem and leaf, respectively. The pattern followed by $\mathrm{Cu}^{2+}$ was entirely different with $42.8 \%$ partitioning in the leaf, followed by $33.1 \%$ in the stem and $23.8 \%$ in the root. It is concluded that different plant tissues have the capacity to accommodate metals but are selective in terms of their need as micronutrients and their relative toxicities. Since $\mathrm{Cd}^{2+}$ is a toxic metal, it is immobilized principally in the root and the remaining bigger chunk in the stem. As both $\mathrm{Cu}^{2+}$ and $\mathrm{Zn}^{2+}$ are micronutrients, these are portioned

Table VI. Accumulation of $\mathrm{Cd}^{2+}, \mathrm{Cu}^{2+}$ and $\mathrm{Zn}^{2+}$ in the root, stem and leaves at different stages of growth of tomato plants grown in metals-contaminated silt-soil

\begin{tabular}{lccccccc}
\hline Stages of plant growth & Plant part & \multicolumn{3}{c}{ Heavy metals contaminated silt-soil } & \multicolumn{2}{c}{ Silt-soil as collected (control) } \\
\cline { 3 - 7 } & & $\begin{array}{c}\mathrm{Cd}^{2+} \\
(\mu \mathrm{g} / \mathrm{g} \mathrm{FW})\end{array}$ & $\begin{array}{c}\mathrm{Cu}^{2+} \\
(\mu \mathrm{g} / \mathrm{g} \mathrm{FW})\end{array}$ & $\begin{array}{c}\mathrm{Zn}^{2+} \\
(\mu \mathrm{g} / \mathrm{g} \mathrm{FW})\end{array}$ & $\begin{array}{c}\mathrm{Cd}^{2+} \\
(\mu \mathrm{g} / \mathrm{g} \mathrm{FW})\end{array}$ & $\begin{array}{c}\mathrm{Cu}^{2+} \\
(\mu \mathrm{g} / \mathrm{g} \mathrm{FW})\end{array}$ & $\begin{array}{c}\mathrm{Zn}^{2+} \\
(\mu \mathrm{g} / \mathrm{g} \mathrm{FW})\end{array}$ \\
\hline Seedling stage (days 1-10; & Root & $(-)$ & $(-)$ & $(-)$ & $(-)$ & $(-)$ & $(-)$ \\
nursery seedlings upto & Stem & $\mathrm{ND}$ & $10.12 \pm 2.1$ & $103.19 \pm 4.8$ & $\mathrm{ND}$ & $9.86 \pm 1.92$ & $54.13 \pm 2.2$ \\
transplantation) & Leaf & $\mathrm{ND}$ & $8.03 \pm 1.05$ & $40.76 \pm 2.6$ & $\mathrm{ND}$ & $5.02 \pm 0.97$ & $10.01 \pm 0.9$ \\
Vegetative Stage & Root & $96.53 \pm 3.19$ & $19.74 \pm 1.9$ & $120.33 \pm 3.6$ & $\mathrm{ND}$ & $11.12 \pm 0.9$ & $12.89 \pm 1.1$ \\
(days 11-40; seedling & Stem & $19.82 \pm 1.72$ & $30.52 \pm 2.2$ & $50.72 \pm 2.6$ & $\mathrm{ND}$ & $24.17 \pm 1.7$ & $67.08 \pm 2.8$ \\
transplantation to flowering) & Leaf & $4.65 \pm 0.92$ & $33.90 \pm 2.5$ & $51.01 \pm 2.3$ & $\mathrm{ND}$ & $7.99 \pm 0.7$ & $14.40 \pm 1.2$ \\
Fruiting Stage & Root & $101.21 \pm 4.3$ & $31.62 \pm 2.0$ & $125.72 \pm 3.1$ & $\mathrm{ND}$ & $14.23 \pm 1.2$ & $16.23 \pm 1.2$ \\
(days 41-75; flowering to & Stem & $30.62 \pm 2.19$ & $44.31 \pm 2.6$ & $58.27 \pm 2.7$ & $\mathrm{ND}$ & $29.27 \pm 1.9$ & $74.64 \pm 3.2$ \\
fruit ripening & Leaf & $7.21 \pm 1.09$ & $56.71 \pm 2.8$ & $55.21 \pm 2.4$ & $\mathrm{ND}$ & $10.12 \pm 0.6$ & $18.30 \pm 1.2$ \\
& Fruit & - & - & - & - & $1.01 \pm 0.07$ & $1.82 \pm 0.06$ \\
\hline
\end{tabular}

All values are mean of concurrent triplicate observations; \pm Standard deviation

(-) roots were not taken for analysis in seedling stage; $\mathrm{ND}=$ not detected; $\mathrm{FW}=$ fresh weight 
in different tissues at different levels, reflecting partly their relative metabolic needs and partly as the immobilized fractions in the tissue sinks.

\section{Acknowledgement}

The authors M. Iqbal and A. Saeed, greatly acknowledge respectively, Alexander von Humboldt $(\mathrm{AvH})$ Foundation, Bonn, Germany for the purchase of Atomic Absorption Spectrophotometer Unicam 969 (Oxford, UK) through their equipment subsidy grant programme to their Fellows, and International Foundation for Science (IFS), Stockholm, Sweden in collaboration with COMSTECH, Islamabad, Pakistan for the purchase of Shimadzu UV-1800 Spectrophotometer (Japan).

\section{References}

Aebi H (1984), Catalase in vitro. Methods Enzymol. 105: 121-126.

Alia P and Saradhi P P (1991), Proline accumulation under heavy metal stress. J. Plant Physiol. 138: 554-558.

Baszynski T, Tukendorf M, Ruszkowska M, Skorzynska E and Maksymiec W (1988), Characteristics of the photosynthetic apparatus of copper non-tolerant spinach exposed to excess copper. J. Plant Physiol. 132: 708713.

Bates L S, Waldern RP and Teare JD (1973), Rapid determination of proline for water stress studies. Plant Soil, 39: 205-207.

Bo S, Mei L, Tongbin C, Yuanming, Z, Yunfeng, X, Xiaoyan L and Ding, G (2009), Assessing the health risk of heavy metals in vegetables to the general population in Beijing, China. J. Environ. Sci. 21: 1702-1709.

Chance B and Maehly AC (1955), Enzymatic assay of peroxidase (E.C. 1.11.1.7) from soybean. Methods Enzymol. II: 773-775.

Chandra R, Bhargava RN, Yadav S and Mohan D (2009), Accumulation and distribution of toxic metals in wheat (Triticum aestivum L.) and Indian mustard (Brassica campestris L.) irrigated with distillery and tannery effluents. J. Hazard. Mat. 162: 1514-1521.

Cheng S (2003), Effect of heavy metals on plants and resistance mechanism. Environ. Sci. Poll. Res. 10: 256-264.

Claire LC, Adriano DC, Sajwan KS, Abel SL, Thoma DP and Driver JT (1991), Effects of selected trace metals on germinating seeds of six plant species. Water Air Soil Poll. 59: 231-240.

Das P, Samantaray S and Rout GR (1997), Studies on cadmium toxicity in plants: a review. Environ. Poll. 98: 2936.
El-Beltagi HS, Mohamed AA and Rashed M (2010), Response of oxidative enzymes to cadmium stress in leaves and roots of radish (Raphanus sativus L.). Notulae Scientia Biologica, 2: 76-82.

Foyer CH, Lopez-Dalgado H, Dat JF and Scott IM (1997), Hydrogen peroxide and glutathione associated mechanism of acclamatory stress tolerance and signaling. Physiologia Plantarum, 100: 241-254.

Gorsuch JW (1991), Plants for toxicity assessment, ASTM Committee E-47 on biological effects and environmental fate. p. 401.

Gratao PL, Monteiro CC, Antunes AM, Peres LEP and Azevedo RA (2008), Acquired tolerance of tomato (Lycopersicon esculentum cv. Micro-Tom) plants to cadmium-induced stress. Ann. App. Biol. 153: 321-333.

Gratao PL, Gomes-Junior RA, Delite FS, Lea PJ and Azevedo RA (2006), Antioxidant stress responses of plants to cadmium. In Cadmium Toxicity and Tolerance in Plants; Khan, N. A. and Samiullah, Eds.; Narosa Publishing House: New Delhi, 1-34.

Grawe KP (1996), Cadmium in our kidneys - from where? Vår Föda, 6: 10-12.

Haghiri F (1974), Plant uptake of cadmium as influenced by cation exchange capacity, organic zinc and soil temperature. J. Environ. Qual. 3: 180-183.

Han XF (2007), Trace element pollution in arid zone soil. In: Biogeochemistry of Trace Elements in Arid Environments; Brain, J. A. and Jack, T. T. Eds.; Environ. Poll. 13, Springer, The Netherlands, 267-287.

Hattab S, Dridi B, Chouba L, Kheder MB and Bousetta H (2009), Photosynthesis and growth responses of pea Pisum sativum L. under heavy metal stress. J. Environ. Sci. 21: 1552-1556.

Israr M, Jewell A, Kumar D and Sahi SV (2011), Interactive effects of lead, copper, nickel and zinc on growth, metal uptake and antioxidative metabolism of Sesbania drummondii. J. Hazard. Mat. 186: 1520-1526.

John R, Ahmad P, Gadgil K and Sharma S (2008), Effect of cadmium and lead on growth, biochemical parameters and uptake in Lemna polyrrhiza L. Plant Soil Environ. 54: 262-270.

Jansson G (2002), Cadmium in arable crops: The influence of soil factors and liming. PhD. Thesis, Swedish University of Agricultural Sciences, Uppsala, Sweden.

Lichtenthaler HK (1987), Chlorophylls and carotenoids: pigments of photosynthetic biomembranes. Methods Enzymol. 148: 350-382. 
Liu Y, Wang X, Zeng G, Qu D, Gu J, Zhou M and Chai L (2007), Cadmium-induced oxidative stress and response of the ascorbate-glutathione cycle in Bechmeria nivea (L.) Gaud. Chemosphere, 69: 99-107.

Meagher RB (2000), Phytoremediation of toxic elemental and organic pollutants. Curr. Opin. Plant Biol. 3: 153162.

Monteiro M, Santos C, Soares AMVM and Mann RM (2009), Assessment of biomarkers of cadmium stress in lettuce. Ecotoxicol. Environ. Safety, 72: 811-818.

Monteiro M, Santos C, Soares AMVM and Mann RM (2008), Does subcellular distribution in plants dictate the trophic bioavailability of cadmium to Porcellio dilatatus (Crustacea, Isopoda)? Environ. Toxicol. Chem. 27: 2548-2556.

Moral R, Palacios G, Gomez I, Navarro-Pedreno $\mathrm{J}$ and Matrix J (1994) Distribution and accumulation of heavy metals $(\mathrm{Cd}, \mathrm{Ni}$ and $\mathrm{Cr})$ in tomato plant. Fresen. Environ. Bull. 3: 395-399.

Nakano Y and Asada K (1981), Hydrogen peroxide is scavenged by ascorbate specific peroxidase in spinach chloroplasts. Plant Cell Physiol. 22: 867-880.

Nayek S, Gupta S and Saha RN (2010), Metal accumulation and its effects in relation to biochemical response of vegetables irrigated with metal contaminated water and wastewater. J. Hazard. Mat. 178: 588-595.

Novozamsky J, Lexmond TM and Houba VJG (1993), A single extraction procedure of soil for evaluation of uptake of some heavy metals by plants. Inter. J. Environ. Anal. Chem. 51: 47-58.

Peris M, Mico C, Recatala L, Sanchez R and Sanchez J (2007), Heavy metal contents in horticultural crops of a representative area of the European Mediterranean region. Sci. Total Environ. 378: 42-48.

Qin T (1994), Effect of cadmium, lead and their interactions on the physiological and biochemical characteristics of Brassica chinensis. Acta Ecologica Sinica, 14: 46-50.

Radojevic M and Bashkin VN (2007), Practical environmental analysis. 2nd Ed. The Royal Society of Chemistry, UK.

Rhoades JD (1982), Soluble salts. In Method of Soil Analysis; Page, A. L. Miller, R. H. Keeney, D. R., Eds.; Part II, (2nd Ed.). American Society of Agronomy, Madison, WI, USA., 167-179.

Rump HH (2008), Laboratory manual for the examination of water, waste water and soil. 3rd Ed. Wiley-VCH, New York.
Saeed A, Iqbal M and H?ll WH (2009), Kinetics, equilibrium and mechanism of $\mathrm{Cd}^{2+}$ removal from aqueous solution by mungbean husk. J. Hazard. Mat. 168: 1467-1475.

Singh RP and Agarwal M (2007), Effects of sewage sludge amendment on heavy metal accumulation and consequent response of Beta vulgaris plants. Chemosphere, 67: $2229-2240$.

Steel RGD and Torrie JH (1996), Principles and procedures of statistics. 3rd Ed. McGraw Hill Publishers, New York.

Szabados L and Savoure A (2009), Proline: a multifunctional amino acid. Trends Plant Sci., 15: 89-97.

Tantrey MS and Agnihotri RK (2010), Chlorophyll and proline content of gram (Cicer arietinum L.) under cadmium and mercury treatments. Res. J. Agri. Sci. 1: 119122.

Walkey I and Black A (1934), An examination of the Degtjareff method for determining soil organic matter and a proposed modification of the chromic acid titration method. Soil Sci. 37: 29-38.

WHO (World Health Organization). (1992) Environmental health criteria. 134 cadmium. IPCS, Geneva, Switzerland.

Wilson B and Pyatt FB (2007), Heavy metal dispersion, persistence, and bioaccumulation around an ancient copper mine situated in Anglesey, UK. Ecotoxicol. Environ. Safety, 66: 224-231.

Wu F.-B, Dong J, Qian QQ and Zhang, G.-P (2005), Subcellular distribution and chemical form of $\mathrm{Cd}$ and $\mathrm{Cd}-\mathrm{Zn}$ interaction in different barley genotype. Chemosphere, 60: 1437-1446.

Yemm EW and Willis AJ (1954), The estimation of carbohydrates in plant extracts by anthrone. Biochem. J. 57: 508-514.

Yobouet YA, Adouby K, Trokourey A and Yao B (2010), Cadmium, copper, lead and zinc speciation in contaminated soils. Inter. J. Eng. Sci. Technol. 2: 802-812.

Yujing C, Xuhong Z and Yongguan Z (2008), Does copper reduce cadmium uptake by different rice genotypes? $J$. Environ. Sci. 20: 332-338.

Received: 05 July 2012; Revised: 04 July 2012; Accepted: 17 December 2013. 